Citation: R. Sommella (2020). Consumption and Retail in Urban Spaces: Studies on Italy and Catalonia. Bollettino della Società Geografica Italiana serie 14, 3 Special Issue: 7-12. doi: $10.36253 /$ bsgi-1263

Copyright: (c) 2020 R. Sommella. This is an open access, peer-reviewed article published by Firenze University Press (http://www.fupress.com/bsgi) and distributed under the terms of the Creative Commons Attribution License, which permits unrestricted use, distribution, and reproduction in any medium, provided the original author and source are credited.

Data Availability Statement: All relevant data are within the paper and its Supporting Information files.

Competing Interests: The Author(s) declare(s) no conflict of interest.

\section{Consumption and Retail in Urban Spaces: Studies on Italy and Catalonia}

\author{
Consumo e commercio negli spazi urbani: una ricerca in Italia e \\ in Catalogna
}

\author{
RosARIO SOMMELLA \\ Dipartimento di Scienze Umane e Sociali, Università degli studi di Napoli “L'Orientale”, Italy \\ E-mail: rsommella@unior.it
}

\section{Changing urban landscapes of retail and consumption}

The choice of a shopping street in UK as the cover picture gives me the opportunity to introduce this special issue: in this country, the health of town centres and high streets has been under scrutiny for the past ten years, at a time when the effects of the global economic crisis were already becoming evident. As evidence of the interest in this topic, in 2011 the report Revitalising High Street ${ }^{1}$ was published, as well as an article in which Wrigley and Dolega - using the concepts of resilience, fragility and adaptation - analysed the performance of more than 250 urban centres and high streets in four regions of the country, and their reconfigurations following the economic shock. A vivid debate followed, marked by different contributions. We have no way of accounting for the variety of opinions and positions expressed; suffice it to mention the works of scholars sometimes directly involved in the planning and management of retail areas, who focused their attention on specific issues: the challenges posed to the high street because of the impact of online retailing, of the rapid growth of the so-called convenience stores, of the consolidation of the night-time economy and of the new factors influencing consumer behaviour (Wrigley, Brookes 2014), or again the trends of commercial and social spaces characterised by an "adaptive flexibility" (Wrigley, Lambiri 2014, 919) that had kept them alive in the past and still constituted a creative presence.

Not only for high streets, these are phenomena and issues that, although articulated in different ways from a geographical point of view, also had several effects in Italy, over the last decade. On the occasion of an international seminar, I had the opportunity to focus on such dynamics: "half a century after the beginning of the transition to the post-Fordist city, we are observing transformations, not only in the central areas, which require us to integrate the interpretation of the changes of the urban economic base with new con-

\footnotetext{
${ }^{1}$ The report, commissioned by the British government, was entrusted to the retail expert Mary Portas (The Portas Review. An independent review into the future of our high streets).
} 
cepts, suitable for grasping the deep change underway in terms of lifestyles, growth of cultural consumption, and responses to the crisis" (Sommella 2015, 233).

In connection with the work of the international research network on City, Retail and Consumption and with the research group of the Italian Association of Geographers I luoghi del commercio fra tradizione $e$ innovazione (Retail places between tradition and innovation $)^{2}$, at the Orientale University in Naples for some years we have been dealing with urban-retail change and consumption practices in Naples and its metropolitan area. Recently we have investigated the topic within the framework of the Research Projects of Relevant National Interest (Italian acronym PRIN), mentioned in the Foreword (Retail, Consumption, and the City: Practices, Planning and Governance for Urban Inclusion, Resilience, and Sustainability), of which this special issue collects the latest products ${ }^{3}$. In all these works, analysing the urban landscapes of retail and consumption has been a way of studying an urban geography in rapid and sometimes fleeting change.

The aim of this special issue was to publish in English, in a prestigious journal, some further reflections than those that had marked the various stages of the work of the group ${ }^{4}$, made up of seven units operating in various parts of Italy, with the addition of the Barcelona team to the Neapolitan one. When we developed the idea of this publishing project, even brief summaries of the research seemed to be significant in offering a cross-section of the retail and consumption's dynamics in some paradigmatic Italian and Catalan urban spaces. Notwithstanding, the ambition was also a different one: that of investigating - through specific in-depth studies (thematic or related to case studies) - aspects not adequately dealt with in the already published volumes, or even to take inspiration from themes and cases already dealt with to advance in a reflection that could contribute to building a further piece of a new research agenda on retail, consumption, and the city. Right from the early stages of the project, it seemed important to us to focus attention, in a perspective of international comparison, on Italian urban spaces and on the multidimensionality of the phenomena that have characterized them in recent times, using retail and consumption as interpretative keys of the changes in the centres and

\footnotetext{
${ }^{2}$ https://www.ageiweb.it/gruppi-di-lavoro/i-luoghi-del-commercio-tratradizione-e-innovazione-2/

${ }^{3}$ For a detailed review of the works of the international and national network, as well as of the publications we have produced on the Neapolitan case-study, see Carreras, D'Alessandro 2017.

${ }_{4}^{4}$ These stages, with their respective results in terms of publications, are summarized in Lida Viganoni's Foreword.
}

suburbs of our cities. The aim was, therefore, to try to fill a knowledge gap not only regarding the consistency and characteristics of retail and entertainment activities, but also on the evolution of spaces and places in relation with consumption practices. In addition, we tried to focus on the relations between the different actors (entrepreneurs, workers, residents, users, and visitors) and the places, by noting the forms of conflict and trying to outline, in this case through a comparison with the Catalan context, innovative interpretations or future perspectives, without neglecting the role of the policies that guide the management of the sector.

By cross-referencing descriptive evidence and theoretical reflections, in this issue we attempted to trace evolutionary and, in some cases, analytical trajectories from different case studies, all aimed at reflecting on the relationship between consumption, retail and urban spaces in Italy and Catalonia at different scales: from the streets (Messina and Sabato) to the neighbourhoods (D’Alessandro and Autiero), from some paradigmatic spaces in urban centres (Albolino and Cappiello) to cities that have experienced recent transformations induced by retail and consumption (Bonazzi, Frixa, Sommella and D'Alessandro, Zilli and Modaffari) and again, in some regional contexts, from the focus on the intraurban scale (Ferrari et al.) to inland areas (Cardinale et al.) and rural areas (Clerici) and, finally, from the metropolitan areas - as those of Catania and Messina (Barilaro et al.) and Barcelona (Carreras et al.) - to the Italian administrative Regions themselves, explored through the territorialisation processes of retail and tourism (Cusimano et al., Nicosia, Porto). Many of the reflections we have developed have, however, in some ways been overtaken by events: although the effects of the COVID-19 crisis on retail and consumption activities are not yet fully clear, and are still being produced at this stage, it is certainly a new challenge for those urban landscapes that have already been so profoundly altered by the dynamics that we analysed in this issue ${ }^{5}$.

Geography has begun to interrogate itself about the first spatial effects of the pandemic, as evidenced by several works devoted to the subject ${ }^{6}$. In relation to

\footnotetext{
${ }^{5}$ Although the focus of the last phase of the research and, therefore, of the contributions collected here was on case studies elaborated before the pandemic crisis, in some cases the field research was interrupted by the crisis itself, while in others the latter has represented an essential element for some brief concluding reflections by the authors on the future of the contexts investigated.

${ }^{6}$ Among others, and dealing with various aspects of the pandemic, the monographic issues of the journals "Documenti Geografici" on Geographies of the Covid-19 (Bozzato 2020) and "Dialogues in Human Geography" on Geographies of the COVID-19 pandemic (Rose-Redwood et al. 2020), as well as the Italian Covid-19 Atlas project (Casti, Adobati 2020).
} 
retail and consumption too, during the pandemic, some scholars have developed reflections on the consequences induced by a health crisis that has had/is having a very significant impact on public spaces and then on the places of retail and consumption that mark the "daily geographies" of markets (Van Eck et al. 2020). This means commercial streets or squares, and all places of commerce in which the consumption of products is closely linked to that of the places and, therefore, of the public spaces themselves ${ }^{7}$. Again, in relation to the components of the urban commercial system, the consumption practices experienced during the most stringent lockdowns in commercial spaces such as supermarkets are cited as paradigmatic practices for retail shops as well: "in a longer timeframe, experiences gained in supermarkets will most probably turn out to be extremely important for all kinds of retail stores. As soon as legislation will step by step relax the regulations on social distancing, the network of practice will most likely expand from the realm of supermarket(s) (chains) to other retailers, for instance in fashion retail or bookstores" (Brinks, Ibert 2020). On the other hand, some of the effects of the crisis were immediately visible on the urban-commercial systems in Italy as well. In our country e-commerce, which was already growing rapidly, has experienced an unprecedented expansion: in one year (2020) - according to data from the eCommerce B2C Observatory of the Politecnico di Milano, reported by the economic-financial newspaper Sole24ore (Mancini 2020) - purchases of products on the web increased by 5.5 billion, marking a growth especially in the food sector. In addition to the natural prominence of the large players and specialised e-retailers, another interesting element was the involvement of small retailers and of the so-called traditional shops, especially in the grocery sector, as well as the growing role of large-scale organised distribution. Unsurprisingly, there has been an authentic rediscovery of neighbourhood commerce: although the phenomenon will have to be assessed over the long term, since it manifested its effects in Italy especially in the months of the strictest lockdown, data from Fida's Observatory showed that during the pandemic almost one in two businesses (47.3\%) active in the food retail sector recorded an increase in new customers ${ }^{8}$.

\footnotetext{
${ }^{7}$ On the role of the crisis in rethinking these spaces at the Neapolitan scale, using the concepts of spatial vulnerability, adaptive resilience, and sustainability, we too have begun to reflect (Sommella, D'Alessandro forthcoming).

${ }^{8}$ For an in-depth analysis of the research, carried out by the Italian Federation of Food Retailers (in Italian FIDA), member of Confcommercio, in collaboration with Format Research, see https://formatresearch. com/2020/09/25/fida-confcommercio-negozi-di-vicinato-con-la-pandemia-piu-clienti-per-unimpresa-su-due-osservatorio-con-format-reseach/, last accessed on 1/9/2021.
}

Beyond persistent prejudices - often changed in motivation or form but not in substance ${ }^{9}$ - regarding retail and consumption, both remain fundamental to understanding where the city is going. Studying consumption, on the other hand, does not mean assuming it uncritically as a way of managing the city, but understanding that it is a fundamental spring, even if it follows fashion - although, it is also redundant to specify, the city has never been and certainly is not now exempt from fashion - in order to understand some of the ways the city as it is lived. This is especially true in terms of attractiveness: the metropolis "attracts irresistibly because it presents itself as the place where you can buy everything you can afford and where what you buy makes what you can afford visible" (Amendola 2016, 17, our translation). However, it is equally clear that the urban future, and with it the wealth and the image of the city, are the outcome of processes and phenomena produced by "stakeholders, place marketing and the demand of a middle class", the last one both protagonist and beneficiary of this philosophy (Amendola 2016, 17), which produces obvious contradictions. Recalling a previous work by Amendola (2010), as we pointed out in this special issue in relation to the Neapolitan case, these are "contradictions that a process connected to the democratization of consumption (of needs, desires, and experiences) and its places entails, starting with the changes in social geography and the new forms of residential segregation and territorial hierarchization" (Sommella, D'Alessandro in this issue).

The contemporary flâneurie spasmodically searches for attractive scapes and the urban tourism in progressive growth, although currently stagnant due to the pandemic crisis, involves profound changes. From this point of view, the sustainability of a city, which especially in the central spaces also for the effect of policies has found in spectacularization a fundamental driver (Sommella 2019), requires - as well as the construction of new spaces, artificial or not, in the suburbs and in the medium-size cities - new and further reflections. On the other hand, these themes offer other food for thought on the socio-spatial changes in cities, in the light of the phenomena with which the emergence of these scapes has to contend (including the pandemic crisis), and on the changes they have produced both in the urban fabric and

\footnotetext{
9 It is worth mentioning here the passage from the sociologist Fabris that we quoted (Sommella D'Alessandro, in this issue), recalling his invitation not to ignore "what consumption represents in our lives today, its symbolic and identity-related meanings, indulging in the oldest demonizations" (Fabris 2010, 3-4); and still not to persist in legitimizing new anathemas "on its hedonistic, expressive, semiotic and identity-related meanings" (Fabris 2010, 3-4).
} 
the built environment of Italian cities and in our everyday experiences of these cities, which are increasingly linked to specific atmospheres of retail and consumption $^{10}$, as highlighted in many of the articles in this issue.

Governance is crucial, even if, in the phase immediately preceding the one we are currently experiencing, it seems to have more than facilitated the trends underway: the revitalization of centres, the pedestrianisations, the expansion of areas allocated to public and private land occupation, with the related conflicts, are real elements and lead to gentrification or profound changes in entire parts of the city. Ultimately, it is a question of assessing the consequences of these dynamics and taking action to avoid the falsification of spaces. On the other hand, the commercial revolution, as well as changing the face of retail places aimed at satisfying simple needs, has produced new commercial spaces in which consumption and desires are sold, aimed at satisfying the demand for shopping and leisure experiences (Cachinho 2014). This does not concern, as we have highlighted in this issue for Naples, only high streets but also other commercial places because "in the postmodern metropolis of new retail spaces and consumer places, deliberately planned to seduce, intercept and create 'consumactor' expectations, the border between the stage and stalls disappears" (Cachinho 2014, 133). It is not a question of supporting consumption, but of looking at the city as a whole, understanding its transformations, including the economic ones, trying to understand the demands of stakeholders, residents, and users without ignoring - even more in the post-pandemic context - the need for social sustainability, resilience and, last but not least, the demands of social justice.

\section{The last phase of the research project}

Against the backdrop of the trends outlined above, the last phase of the research was marked by work of different angles, which sometimes even within the same research unit led to an analysis of the urban landscapes of retail and consumption by means of a wide variety of concepts, theoretical and methodological approaches. This gave rise to a wealth of perspectives on the selected case studies, contributing to progress in the reflections undertaken in the other phases of the project.

The case of the research unit "L'Orientale", with its focus on Naples, Matera, and Barcelona, certainly exem-

\footnotetext{
${ }^{10}$ On the importance of producing new urban atmospheres - real or artificially constructed for the purposes of retail and consumption - see our contribution (D’Alessandro et al. 2018).
}

plifies this variety. Starting from the historical importance of the commercial function in structuring the Neapolitan urban space and from the links of this function with the change of the urban image, D'Alessandro and I have briefly traced the long-term relationship between consumption and demand for places. More specifically, the transcalar analysis allowed us to focus on cases in which the demand for products and places is one possible evolution of a new demand for the city, highlighting the contradictions and conflicts of a Mediterranean city in transition. Even the changes that have recently taken place in the Neapolitan neighbourhood of Vomero appear more readable through the interpretative key of urban-retail changes and consumption practices. D'Alessandro and Autiero develop their reflections based on a field survey, outlining the characteristics of a micro-space, which - especially in the core area of its polarizing nodes - is disputed among various actors and, from an urban-commercial point of view, symbolizes the tension between forms of innovation and embeddedness. The main contemporary trends in retail and consumption are the subject of Carreras, Frago and Montesinos' contribution, but at a different scale: that of metropolitan Barcelona, framed in the Catalan context. Based on almost thirty years of research on the subject, the Authors emphasize the need for a reconfiguration of the scales of analysis, then concentrating on the case of Barcelona. Focusing on changes in the traditional centrality of the Catalan capital, they lay the foundations for outlining some possible future directions. In the contribution by Albolino and Cappiello, the changes in commerce and consumption are instead crossed with the effects of the tumultuous tourist development that has invested the city of Matera, in turn amplified by the event-process European Capital of Culture. The analysis is focused on the transformation of the historic district of the Sassi, in which the reconversion of commercial spaces, mainly for tourism purposes, has produced a marked expansion of the food \& drink segment, which allows the Authors to emphasize both the specific characteristics of the Sassi and those of an urban development increasingly characterized by touristification.

These phenomena are similar to those recently faced by a greater city as Bologna, whose most recent trends have been outlined by the members of the research unit through two perspectives. Bonazzi analysed the standardised process of city branding that has led, since 2014, to a restructuring of urban public space, redefining the "emotional territory" of its citizens through an active remodelling or branding of urban policies. In the light of Baudrillard's analytical categories relating to the "fourth, the fractal (or viral, or radiant) stage of value", the Author exam- 
ines the pandemic and the quarantine landscape, which has made even more evident the fragilities and the very crisis of the branding process symbolized by the generative City of Food logo. The practices and discourses of city promotion that have accompanied the recent transformations of Bologna's urban space are analysed by Frixa through the exploration of connections to changes in commerce and consumption and their meaning. The regeneration processes connected to food, which have redefined the sociospatial fabric of some areas of the city, represent the track through which the Author deconstructs the optimistic readings of the city of Bologna, highlighting the phenomena of exclusion and displacement.

The multiplicity of the geographies of commerce in the heterogeneous territory of Abruzzo is the subject of the analysis of the Chieti-Pescara research unit, which focuses on a two-speed growth of the commercial sector between the coastal and inland areas of the region. Cardinale, Di Matteo, Pascetta and Zarrilli focus on several towns in the Apennine inland of Abruzzo, analysing urban commercial policies and, more generally, some public policies. The analysis of policies that have a different impact on the urban-commercial structure of different regional areas is conducted through the lens of retailers' and consumers' perceptions, which also allows the Authors to suggest some indications for future policies. The Pescara-Chieti area, which has played a polarising role within the urban structure of Abruzzo since the 1950s, is instead analysed by Ferrari, Iacuone, Scorrano and Fuschi with particular attention to the role of commerce as a vehicle for convergence and territorial cohesion, but also in relation to the marginalisation of certain forms of urban commerce. Going beyond the dichotomous opposition between peripheral commercial formats and commercial activities in central areas, the Authors propose an interpretation on an intra-urban scale, with the aim of promoting a balanced and sustainable reorganisation of the city.

The Messina research unit, previously based in Macerata, explores two reflections on the Marche region. Nicosia analyses the new elements of the regional tourist offer, focusing on leisure shopping and fashion tours. After framing the evolution of the region as a tourist destination over the last decade within the national and international context, the Author explores the construction of the Marche's territorial brand: by means of a field survey and some interviews, he outlines a number of itineraries for shopping tourism, trying to identify the relationships between the two sectors. Porto's contribution is instead centered on the Ancona case. Tracing the processes of commercial modernisation and the reconfiguration of the centre-periphery relationship, the
Author frames the urban landscape of Ancona, highlighting the new commercial hierarchies produced by the suburban territorialisation of the large commercial polarities. Based on this framework, the focus shifts to the complexity of Ancona's urban system and its commercial network, as well as to the need for policies aimed at reconciling the revitalization of local identity with forms of competitiveness at a global scale.

The article by Clerici, result of the work of the research unit of the Milan Polytechnic, analyses the processes of commercial restructuring in Lower Lombardy: the approach adopted is aimed at investigating a context considered marginal and peripheral, compared to those of the large urban areas on which most studies of commercial geography focus. Demographic size and position in the urban network are the variables taken into consideration to examine the commerce restructuring processes that characterised the municipalities of the chosen area in the period 2001-2019. The analysis restores the complexity of the evolutionary trajectories of the different municipalities and the relationships among them, but at the same time highlights worrying phenomena of rarefaction of the commercial supply of food, which elsewhere represented the prelude to the so-called food deserts.

The Palermo research unit examines, at different scales and from different perspectives, the most recent evolutionary trajectories of commercial spaces. Barilaro, Cirelli, Graziano and Mercatanti analyse, through the point of view of commercial geography, the territorial reconfiguration of the metropolitan areas of Catania and Messina. After a historical framework on the transformations of retail spaces and consumption practices that have marked the two main metropolitan areas of Eastern Sicily, these are explored with particular attention to the spread of new suburban formats, which have radically changed the centre-periphery relationships. The contribution by Cusimano, Cannizzaro, Giannone and Privitera, broadening the look at the Sicilian dynamics and comparing them with those of whole country, examines the structural changes (including the increase in largescale distribution) and spatial changes (mainly due to the transfer of many activities to the suburbs and out-of-town areas) of commerce, as well as the impact of the 2008 crisis. Using data on the size and distribution of commercial enterprises, the Authors highlight a still widespread presence of small businesses on the territory, testifying to the flexibility of regional micro-enterprises. Messina and Sabato focus, instead, on four Palermo commercial axes, considered symbolic of the change in the urban landscape because of changing consumption habits. In order to analyse the origin and commercial evolution in these strategic areas of the historic centre, identifying the 
permanence and changes of the four different evolutionary trajectories, the Authors adopt a synchronic and diachronic approach. The analysis is enriched by the results of a survey addressed to shopkeepers, aimed at investigating the perception of the sector's operators on urbancommercial and consumption changes.

The article by Zilli and Modaffari, result of the last phase of the research of the Trieste unit, analyses the case of Trieste by intersecting changes in trade and tourism. By framing the urban changes and their impact at various scales, the Authors examine the territorial indeterminacy, which is traced back to the narrowness of the administrative and political space. The most recent renewing of the city's image through new commercial and tourist activities is analysed by focusing not only on the phenomena of redevelopment and gentrification of the central areas but also on an event, the Barcolana, which symbolises a new relationship between the promotion of the urban image and the reshaping of the relationship between the city and the sea.

Finally, the afterword by Carreras, Martínez-Rigol and Morcuende shifts the focus to more general issues, offering an overview of contemporary phenomena in the global economy but also of the social, political, and cultural issues that have most affected the changes in consumer society at the global and urban scale. Retracing some processes (such as those of differential urbanisation) and new conceptions of the urban (among all, planetary urbanisation), the Authors examine the effects of the 2008 economic crisis and on the more recent effects of the health crisis to relaunch the need for new theoretical-methodological tools to develop new interpretative perspectives.

\section{References}

Amendola, G. (2010). Tra Dedalo e Icaro. La nuova domanda di città. Roma-Bari, Laterza.

Amendola, G. (2016). Le retoriche della città. Tra politica, marketing e diritti. Bari, Edizioni Dedalo.

Bozzato, S. (Ed.) (2020). Geografie del Covid-19. Documenti Geografici, 1, http://dx.doi.org/10.19246/DOCUGEO2281-7549/202001_01

Bricks, V., Ibert, O. (2020). From Corona Virus to Corona Crisis: the Value of an Analytical and Geographical Understanding of Crisis. Tijdschrift voor Economische en Sociale Geografie, 111 (3), 275-287.

Cachinho, H. (2014). Consumerscapes and the resilience assessment of urban retail systems. Cities, 36, 131-144.
Carreras, C., D’Alessandro, L. (2017). Un repertorio bibliografico su commercio, consumo e città. In Viganoni, L. (Ed.). Commercio, consumo e città. Quaderno di lavoro. Milano, FrancoAngeli, 27-69.

Casti, E., Adobati, F. (Eds.). (2020). Mapping riflessivo sul contagio del Covid-19. Dalla localizzazione del fenomeno alla sua importanza territoriale, $1^{\circ}, 2^{\circ}$ e $3^{\circ}$ rapporto di ricerca. Bergamo, CST, Università degli studi di Bergamo, https://cst.unibg.it/it/ricerca/progetti-ricerca

D’Alessandro, L. Sommella R., Viganoni, L. (2018). Atmospheres of and in Geography. In Griffero, T., Moretti, G. (Eds.). Atmosphere/Atmospheres: Testing A New Paradigm. Mimesis International, Milano, 31-45.

Fabris, G. (2010). La società post-crescita. Consumi e stili di vita. Milano, Egea.

Mancini, G. (25/11/2020). Il Covid accelera le vendite online. il Sole24ore, https://www.ilsole24ore.com/art/ilcovid-accelera-vendite-online-ADCHBw1

Rose-Redwood, R., Kitchin, R., Apostolopoulou, E., Rickards, L., Blackman, T., Crampton, J., Rossi, U., Buckley, M. (2020). Geographies of the COVID-19 pandemic. Dialogues in Human Geography, 10 (2), 97-106, https://doi.org/10.1177/2043820620936050

Sommella, R. (2015). Nuove forme del commercio e dei servizi nei contesti urbani. In D’Alessandro, L. (Ed.). City, Retail and Consumption. Napoli, Università degli studi "L'Orientale", 233-238.

Sommella, R (2019). Il territorio della ricerca: fuori e dentro Napoli. In Viganoni, L. (Ed.). Commercio e consumo nelle città che cambiano. Napoli, città medie, spazi esterni. Milano, FrancoAngeli, 53-72.

Van Eck, E. (2020). Marketplaces as Public Spaces in Times of the Covid-19 Coronavirus Outbreak: First Reflections. Tijdschrift voor Economische en Sociale Geografie, 111 (3), 373-386.

Wrigley, N., Brookes, E. (Eds.) (2014). Evolving High Street. Resilience \& Reinvention: Perspectives from Social Sciences. Southampton, University of Southampton, ESRC.

Wrigley, N., Dolega, L. (2011) Resilience, Fragility and Adaptation: New Evidence on the Performance of UK High Streets during Global Economic Crisis and its Policy Implications. Environment and Planning A, 43 (10), 2337-2363.

Wrigley, N., Lambiri, D. (Eds.) (2014). High Street Performance and Evolution: A brief guide to the evidence. Southampton, University of Southampton, ESRC. 